\title{
IDENTIFIKASI KANDUNGAN POLISAKARIDA BETA GLUKAN PADA JAMUR GANODERMA (Ganoderma lucidum)
}

\author{
Novi Fajar Utami, Sri Wardatun, Fitri Atika Suri \\ Program Studi Farmasi, Fakultas Matematika dan Ilmu Pengetahuan Alam \\ Universitas Pakuan \\ Email : novi.utami@unpak.ac.id
}

\begin{abstract}
ABSTRAK
Jamur ganoderma (Ganoderma lucidum) menghasilkan senyawa aktif polisakarida beta glukan yang berkhasiat sebagai antihiperglikemia. Tujuan penelitian ini untuk mengidentifikasi senyawa polisakarida beta glukan serta mengukur kadar rendemen ekstrak air dan ekstrak alkali dari jamur ganoderma. Ekstraksi dilakukan dengan metoda dekoks untuk pelarut air dan metoda maserasi untuk pelarut alkali. Identifikasi dilakukan berdasarkan panjang gelombang maksimum dan gugus fungsi yang terdapat pada isolat hasil Kromatografi Lapis Tipis (KLT) yang dibandingkan dengan senyawa beta glucan standar dari tanaman barley. Rendemen hasil ekstraksi dengan pelarut air adalah sebesar 2,8\% dan rendemen hasil ekstraksi dengan pelarut alkali adalah sebesar 5,309\%. Hasil identifikasi dengan KLT didapat nilai Rf untuk ekstrak air 0,5875; untuk ekstrak alkali 0,8; dan standar barley 0,625. Panjang gelombang maksimum isolat ekstrak air $268 \mathrm{~nm}$, isolat ekstrak alkali $268 \mathrm{~nm}$ dan standar barley $265 \mathrm{~nm}$. Gugus fungsi yang diperoleh baik isolat ekstrak air dan isolat ekstrak alkali adalah O-H, C-H, C-OR (eter) yang hasilnya sama dengan standar barley yang menunjukkan adanya senyawa beta glukan.
\end{abstract}

Kata kunci : Ganoderma lucidum, beta glukan, standar barley

\section{COMPOUND IDENTIFICATION OF POLISACCHARIDA BETA GLUCAN CONTENT IN MUSHROOM GANODERMA (Ganoderma lucidum)}

\begin{abstract}
Ganoderma mushroom (Ganoderma lucidum) produce the beta glucans polisaccharide active compound which show strong antihiperglikemic effect. The purpose of this research were to identified the beta glucans polysaccharide compounds and measured the concentrate of extract obtained from water and alkali extractions. The beta glucan polysaccharide compound was identified using spectrophotometry and thin layer chromatography (TLC) methods, using beta glucans barley as a standard. The decoction method was applied for water solvent and maceration methods for alkali solvent. The concentrate mass obtained from water extract and alkali extract were $2.8 \%$ and $5.309 \%$ respectively. The $\mathrm{Rf}$ detected on chromatogram were 0.5875 for water extract and 0.8 for alkali extract meanwhle the barley standard has $0.625 \mathrm{Rf}$ value. The maximum wavelength of isolates from water and alkali extracts were $268 \mathrm{~nm}$ and $268 \mathrm{~nm}$ respectively meanwhile the Barley standard has $265 \mathrm{~nm}$. The functional groups obtained from both water and alkali extract isolates were $\mathrm{O}-\mathrm{H}, \mathrm{C}-\mathrm{H}, \mathrm{C}-\mathrm{OR}$ (eter) which were similar to the barley standard. All the present results indicating the presence of beta glucan compound in ganoderma mushroom.
\end{abstract}

Keywords: Ganoderma lucidum, beta glucan, barley standard.

\section{PENDAHULUAN}


Ganoderma adalah jamur yang mudah ditemui disemua iklim, tumbuh pada kayu dengan atau tanpa batang, berbentuk seperti kipas berwarna kuning atau cokelat pada lapisan dalam dan umum digunakan sebagai bahan obat-obatan tradisional Asia. Komposisi jamur terutama terdiri dari air, protein, lemak, karbohidrat, serat, abu, dan beberapa jenis vitamin danmineral. Seperti kalsium, kalium, fosfor, magnesium, selenium, zat besi, zinc, dan tembaga. Beberapa jenis jamur ganoderma mengandung bahan bioaktif spesifik seperti ganoderan asam ganodermin dan polisakarida germanium yangtidak diperoleh dari tumbuhan lain (Jaelani, 2008).

Polisakarida adalah metabolit primer tumbuhan berupa rantai atau polimer dari monomer-monomer monosakarida.

Polisakarida di alam dihasilkan oleh semua tumbuhan dan sebagian besar mikroorganisme seperti pada bakteri, kapang, jamur dan alga, (Prahastuti et al., 2001). Glukan adalah suatu jenis polisakarida dengan monomer berupa Dglukosa yang banyak terdapat pada dinding sel bakteri, tumbuhan dan khamir.

Polisakarida glukan memiliki

aktifitas biologis imunomodulator dan anti hiperglikemia (Wahyudi dan Priyanro, 2010). Berdasarkan penelitian Susanto (1998) jamur Ganoderma memiliki kandungan utama senyawa polisakarida, terpenoid, asam ganodermik, germanium, protein, adenosin dan serat yang memiliki aktivitas sebagai antitumor, meningkatkan oksigen dalam otak, menyeimbangkan fungsi bioelektrik, menurunkan kadar gula dan kolesterol dalam darah, menghilangkan racun dan menghaluskan kulit. Hasil penelitian Indriani et al., (2015) menyatakan bahwa jamur ganoderma dengan kandungan terpenoidnya dapat menghambat aktivitas enzim $\alpha$ glukosidase dan dapat menurunkan kadar glukosa darah tikus yang telah diinduksi hiperglikemia.

Isolasi dan identifikasi polisakarida beta glukan dapat dilakukan dengan metode ekstraksi berdasarkan pada sifat kelarutannya. Menurut Widyastuti (2011) senyawa aktif beta glukan mempunyai sifat larut dalam air dan alkali sehingga polisakarida beta glukan dapat diekstraksi dengan cara dekoksi untuk ekstraksi dengan pelarut air dan maserasi untuk ekstraksi dengan pelarut alkali $(\mathrm{NaOH})$. Ekstrak diisolasi dengan menggunakan metode Kromatografi Lapis Tipis (KLT). Isolat beta glukan selanjutnya dilakukan identifikasi dengan menggunakan spektrofotometri UV-Vis dan FTIR (Khopkar,2003). Hasil dari analisis dibandingkan dengan standar Barley, karena menurut Widyastuti (2009) Barley merupakan salah satu tanaman selain Oats yang memiliki kandungan beta glukan paling tinggi.

\section{METODE PENELITIAN}

Penelitian ini dilakukan di Laboratorium Farmasi Universitas Pakuan Bogor dan di Laboratorium Akademi Kimia Analis Bogor.

\section{Bahan}

Jamur Ganoderma kering, standar Barley, akuades, natrium hidroksida, asam asetat, etanol $80 \%$, astonitril, butanol, metanol, serta pereaksi untuk uji fitokimia dan uji karbohidrat.

\section{Alat}

Grinder, oven, tanur, plat KLT, chamber, sentrifugase (Camag $\left.{ }^{\circledR}\right)$, freeze dryer $\left(\right.$ Eyela $\left.^{\circledR}\right)$, spektrofotometri UV-Vis $\left(\right.$ Jasco $\left.^{\circledR}\right), \quad$ spektrofotometri $\quad$ FTIR $\left(\right.$ Bruker $\left.^{\circledR}\right)$, refrigerator, beserta alat-alat gelas yang lainnya. 


\section{Cara Kerja}

\section{Pembuatan Ekstrak}

Ekstraksi dilakukan berdasarkan metoda Widyastuti (2011) yaitu metode dekoksi untuk pelarut air dan maserasi untuk pelarut alkali dengan perbandingan pelarut 1:10. Sebanyak 100 gram simplisia diekstraksi dengan $1000 \mathrm{ml}$ akuades pada suhu $100^{\circ} \mathrm{C}$ selama 1 jam kemudian disaring. Filtrat diinkubasi dengan penambahan $500 \mathrm{ml}$ etanol $80 \%$ pada suhu $4^{\circ} \mathrm{C}$ selama 1 hari. Ekstrak kemudian disentrifugasi dan endapannya dikeringkan dengan mesin freeze dryer.

Residu ekstrak air kemudian digunakan untuk ekstraksi alkali. residu ditambahkan natrium hidroksida sebanyak $1000 \mathrm{ml}$ kemudian didiamkan selam 2 jam, sesekali dilakukan pengadukan, selanjutnya disaring. Filtrat dinetralisasi dengan penambahan asam asetat kemudian diinkubasi pada suhu $4^{\circ} \mathrm{C}$ selama 1 hari. Ekstrak disentrifugasi dan endapannya dikeringkan dengan menggunakan freeze dry. Dihitung masing- masing rendemen ekstrak air dan ekstrak alkali.

Pemeriksaan mutu ekstrak meliputi: rendemen ekstrak, kadar air, kadar abu, uji fitokimia simplisia dan ekstrak, uji karbohidratn ekstrak.

\section{Analisis Senyawa Beta Glukan dengan Kromatografi Lapis Tipis (KLT) KLT Analitik}

Plat silika disiapkan dan diatur jarak antara batas penotolan dan batas akhir elusi. Chamber diisi dengan eluen asetonitril:butanol:air (3:6:1) kemudian dijenuhkan. Plat yang telah ditotolkan dengan sampel dan standar Barley dikembangkan dalam chamber sampai eluen mencapai batas akhir elusi. Hasil elusi kemudian diamati menggunakan sinar UV $254 \mathrm{~nm}$ dan $366 \mathrm{~nm}$ dan dihitung nilai $\mathrm{Rf}$ dan dibandingkan dengan nilai Rf standar barley (Mursito, 2012). Standar barley adalah senyawa polisakarida beta glukan yang diperoleh dari tanaman barley.

\section{KLT Dua Dimensi}

Noda pada KLT analitik dikerok dan ditambahkan dengan pelarut ekstraksi masing-masing kemudian disentrifugasi dengan penambahan eluen asetonitril:butanol:air (6:3:1) untuk ektrak air dan eluen asetonitril:methanol (6:4) untuk ekstrak alkali. Biarkan masingmasing eluen hingga jenuh. Isolat kemudian ditotolkan pada plat kemudian dilakukan elusi pertama, setelah elusi pertama selesai kemudian dilanjutkan elusi kedua. Hasil elusi kedua diamati dengan sinar UV pada panjang gelombang $254 \mathrm{~nm}$ dan $366 \mathrm{~nm}$, dan dihitung nilai Rf masingmasing elusi. Isolat tunggal hasil elusi dua dimensi kemudian diperbanyak dengan KLT preparatif.

\section{Identifikasi Senyawa Beta Glukan dengan Spektrofotometri UV-Vis}

Disiapkan isolat dari masing-masing ekstrak air dan ekstrak alkali serta standar Barley. Blanko akuades/ $\mathrm{NaOH}$ dimasukan kedalam kuvet pertama, sampel ekstrak dimasukan kedalam kuvet kedua kemudian dilakukan pemindaian (scanning). Hasil panjang gelombang maksimum akan terdeteksi beserta nilai absorbansi.

\section{Identifikasi Senyawa Beta Glukan dengan Spektrofotometri FTIR}

Masing-masing sebanyak $2 \mathrm{ml}$ isolat sampel dan standar dicampur dengan 200 mg serbuk $\mathrm{KBr}$ kering hingga homogen. Campuran tersebut kemudian dimasukkan kedalam pencetak cakram, dilanjutkan dengan scanning cakram $\mathrm{KBr}$ dengan frekuensi antara $400-4000 \mathrm{~cm}^{-1}$.

\section{HASIL DAN PEMBAHASAN Hasil Ekstraksi}

Rendemen hasil ekstraksi sample kering jamur ganoderma dengan pelarut air adalah sebesar $2,8 \%$ dan rendemen hasil 
ekstraksi dengan adalah sebesar 5,309\%. Hasil ini lebih tinggi dibandingkan dengan penelitian yang dilakukan oleh Indriani et al. (2015) yang mendapatkan rendemen sebesar 0,24\% dari ekstrak dengan pelarut air. Proses ekstraksi yang dilakukan berdasarkan kelarutan senyawa dalam pelarut yang digunakan dapat meningkatkan hasil dari rendemen ekstrak yang didapat (Widyastuti, 2009). Penampilan fisik rendemen ekstrak jamur ganoderrma dapat dilihat pada Gambar 1.

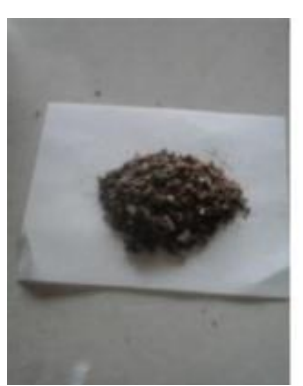

a

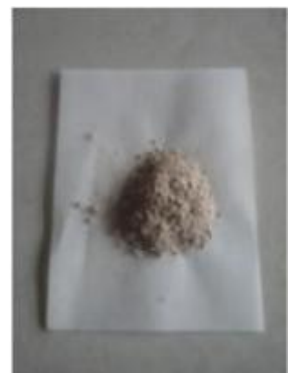

b
Gambar 1. a) ekstrak Alkali, b) ekstrak Air

Hasil pengujian kadar air ekstrak jamur Ganoderma dengan pelarut air adalah 5,2345\% dan kadar air ekstrak dengan pelarut alkali adalah 7,3018\%. Hasil ini memenuhi syarat kadar air untuk ekstrak kering jamur Ganoderma yaitu $8,13 \%$ (Pranamuda, 2012).

Hasil uji fitokimia menunjukan bahwa jamur ganoderma positif mengandung senyawa golongan terpenoid. Hasil yang diperoleh sesuai dengan hasil penelitian sebelumnya yang menyatakan bahwa jamur Ganoderma mengandung senyawa golongan terpenoid (Indriani, 2015).

Hasil uji karbohidrat menunjukkan bahwa ekstrak mengandung glukosa yang merupakan monomer penyusun polisakarida beta glukan (Akhirunnisa, 2010).

\section{Hasil Analisis Kromatografi Lapis Tipis (KLT)}

Hasil dari KLT analitik diperoleh nilai Rf untuk ekstrak air 0,5875, ekstrak alkali 0,8 dan standar Barley 0,625. Berdasarkan perbandingannya terhadap standar nilai Rf tidak jauh berbeda menandakan senyawa yang dimiliki hampir sama. Hasil dari KLT analitik dapat dilihat pada Gambar 2.

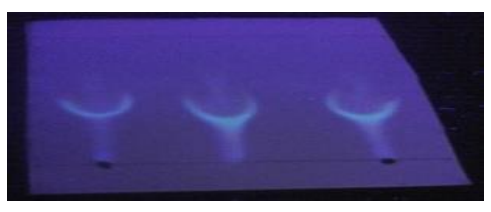

A $S \quad B$

Gambar 2. (A) Elusi Ekstrak air

(B) Elusi Ekstrak alkali

(S) Elusi Standar Barley
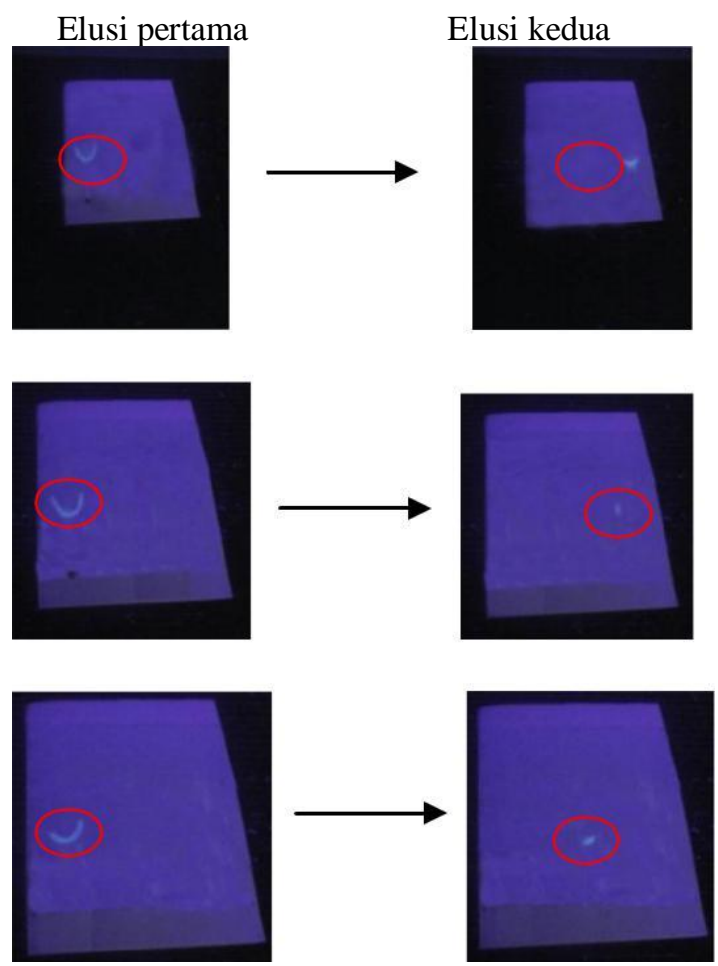

Gambar 3 : Hasil KLT dua dimensi isolat air, isolat alkali dan standar Barley

Hasil isolat KLT analitik kemudian dielusi dengan KLT dua dimensi. KLT dua dimensi dilakukan untuk memisahkan beta glucan dari senyawa-senyawa lain yang memiliki kelarutan sama sehingga didapat senyawa beta glukan agar senyawa yang lebih murni. Hasil KLT dua dimensi dapat dilihat pada Gambar 3. 
Hasil Analisis Spektrofotometri UV-Vis

Berdasarkan hasil scanning dengan spektrofotometer diperoleh panjang gelombang maksimum masing-masing isolat hasilnya tidak berbeda jauh dengan standar. Hal ini membuktikan bahwa senyawa yang terdapat pada isolat ekstrak air dan alkali adalah sama dengan standar yaitu beta glukan. Hasil panjang gelombang maksimum dapat dilihat pada Tabel 1.

Tabel 1. Panjang Gelombang Maksimum

\begin{tabular}{cc}
\hline Isolat & $\begin{array}{c}\text { Panjang Gelombang } \\
\text { Maksimum }(\mathrm{nm})\end{array}$ \\
\hline Standar & 265 \\
Ekstrak air & 268 \\
Ekstrak alkali & 268 \\
\hline
\end{tabular}

\section{Hasil Analisis Spektrofotometri FTIR}

Analisis beta glukan dilakukan dengan membandingkan peak (puncak) yang muncul pada isolat sampel dengan peak standar Barley. Hasil spektrum FTIR dapat dilihat pada Gambar 4.

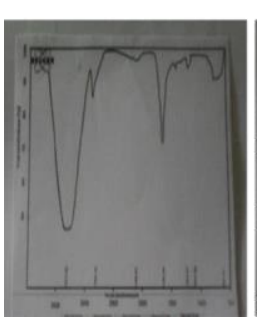

A

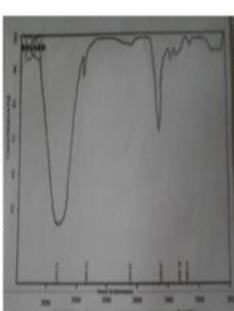

B

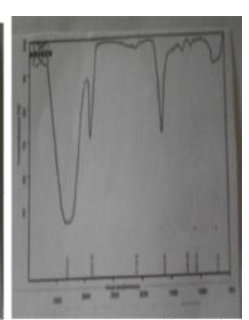

$\mathrm{C}$
Gambar 4 : (A) Isolat ekstrak air,

(B) Isolat ekstrak alkali,

(C) Isolat standar Barley

Spektrum yang diperoleh menunjukkan bahwa sampel dan standar memiliki gugus fungsi yang sama yaitu gugus $\mathrm{O}-\mathrm{H}, \mathrm{C}-\mathrm{H}$, dan $\mathrm{C}-\mathrm{OC}$ (eter). Hasil tersebut mengkonfirmasi bahwa pada sampel terdapat gula yang berikatan dengan ikatan glikosida yang menandakan bahwa senyawa tersebut adalah beta glukan.

\section{KESIMPULAN DAN SARAN Simpulan}

Ekstraksi berdasarkan kelarutan terhadap air dan alkali menghasilkan rendemen ekstrak air sebesar 2,8\%dan ekstrak alkali 5,309\%. Berdasaran data spektrum FTIR isolat ekstrak air dan alkali mengandung senyawa beta glukan yang ditunjukkan oleh adanya ikatan glikosida yang ditunjukkan oleh gugus $\mathrm{O}$ $\mathrm{H}, \mathrm{C}-\mathrm{H}$ dan C-OC (eter).

\section{Saran}

Perlu dilakukan analisis lanjutan menggunakan spektrofotometri NMR dan LCMS untuk mengetahui struktur molekul senyawa beta glukan. Perlu dilakukan juga penelitian lanjutan untuk mengetahui aktifitas antihiperglikemik ekstrak jamur Ganoderma secara in vitro dan in vivo.

\section{UCAPAN TERIMA KASIH}

Ucapan terimakasih kami sampaikan kepada Program Studi Farmasi, Universitas Pakuan, Bogor.

\section{DAFTAR PUSTAKA}

Akhirunnisa, D.F. 2010. Uji Hepatoprotektif Ekstrak Etanol 50\% Jamur Lingzhi (G. lucidum) Pada Tikus Jantan Yang Diinduksi Parasetamol. Skripsi. Fakultas Farmasi Universitas Muhammadiyah Surakarta. Surakarta.

Indriani, R.D., N. Suarsan. dan I.W. Sudira. 2015. Kemampuan Ekstrak Jamur Lingzhi Dalam Menghambat $\alpha$-Glukosidase dan Menurunkan Kadar Gula Darah Pada Tikus Hiperglikemia. Jurnal Veteriner. 16 (2): 220-226. 
Jaelani. 2008. Jamur Berkhasiat Obat. Pustaka Obor Populer. Jakarta. Hal. 60-78.

Khopkar, S.M. 2003. Konsep Dasar

Kimia Analitik. Universitas Indonesia Press. Jakarta. Hal 231237.

Mursito, B. dan R. Sari. 2012. Elusidasi Struktur Senyawa Beta Glukan Dari Serat Jamur Shitake (Lentinus edodes Berk.) yang larut dalam air menggunakan metode spektrometri. Fitofarmaka. 2 (1): 42-52.

Prahastuti, S., R. Tambunan dan R. Rahayu. 2001. Jamur: Kandungan Kimia Dan Khasiat. Pusat Dokumentasi dan Informasi Ilmiah LIPI. Jakarta.

Pranamuda, H., R. Giami dan A. Pradana. 2012. Aplikasi Beta Glukan Sebagai Bahan Berkhasiat Immunomodulator dan Anti Kanker. Prosiding InSINAS

Susanto, A. 1998. Sifat -

Sifat Biokimia Dan Fabrikasi

Ganoderma Jamur Pathogen

Tumbuhan. Jurnal Perlindungan

Tanaman Indonesia. 4 (2): 83-94.

Wahyudi, P. dan P. Priyanro. 2010. Uji Aktivitas Imunomodulator

Polisakarida Jamur Tiram Putih (Pleurotus ostreatus) Dan Jamur Shiitake (Lentinula edodes) Berdasarkan Aktivitas Dan Kapasitassel Makrofag Peritoneum Mencit Secara Invitro. Farmasains. 1 (1): 7-11.

Widyastuti, N., B.Teguh, G. Reni, I. Hengky dan W. Priyo. 2011. Analisa kandungan beta glukan larut air dan larut alkali dari tubuh buah jamur tiram (Pleurotus ostreatus) dan Shiitake (Lentinula edoses). Jurnal Sains dan Teknologi Indonesia. 13 (3): 82-191 .

Widyastuti, N. 2009. Jamur

ShiitakeBudidaya
Pengolahan Si Jamur Penakluk Kanker. Lily Publisher. Jakarta 
